\title{
FUTURE TEACHERS OF HUMANITIES'S \\ PEDAGOGICAL MASTERY FORMATION \\ USING INTERACTIVE TECHNOLOGIES
}

\section{Romanyshyna Oxana ${ }^{1}$ \\ Figol Natalia ${ }^{2}$}

DOI: dx.doi.org/10.30525/978-9934-571-30-5_31

Abstract. The analysis of the scientific investigations concerning future teachers of humanities pedagogical mastery formation in pedagogical theory and practice has been carried out. The essence of pedagogical mastery (pedagogical mastery is considered as a combination of psychological and pedagogical erudition, professional abilities and pedagogical technique), the features of the process of professional training of future teachers in higher educational institutions have been characterized (professionally expedient, individually creative and optimal); the specifics of pedagogical skills of teachers of humanitarian specialties have been revealed; the possibilities of creative use of means of interactive technologies in teachers' professional training have been revealed. The following methods and means of interactive technologies have been defined and substantiated: co-operative education (work in pairs, students' integration into teams with three representatives, carousel, work in small groups, aquarium); education in groups (microphone, unfinished sentences, brainstorming, learning while teaching, problem solving, decision tree); situational education (stimulating or simulation games, public hearings); processing of discussion issues (discussion, debate, PRES method, taking a position, position change, uncontinuous scale of thoughts), etc. It has been found out that a comprehensive research of the practical mechanisms for the pedagogical mastery formation using pedagogical innovations of an interactive nature was not practically carried out. The generalization of scientific approaches to the concept of

\footnotetext{
${ }^{1}$ Doctor of Pedagogical Sciences, Associate Professor,

Associate Professor of the Department of Informatics and its Teaching Methods,

Ternopil Volodymyr Hnatiuk National Pedagogical University, Ukraine

${ }^{2}$ Candidate of Pedagogical Sciences,

Associate Professor of the Department of Pedagogy and Psychology,

Regional Humanitarian and Pedagogical Academy of Taras Shevchenko in Kremenets, Ukraine
} 


\section{Chapter 13. Pedagogical sciences}

"pedagogical conditions" understanding allowed to ground pedagogical conditions for the future teachers' pedagogical mastery formation by means of interactive technologies: educational process improvement through the development of motivation to the acquisition of pedagogical mastery using means of interactive technologies; gradual formation of pedagogical skills through pedagogical probation practice and extracurricular activities; provision of subject-subject interaction of the teacher and students in the process of pedagogical mastery formation by means of interactive technologies. The chosen pedagogical conditions proved to be effective in the presence of a model for the of pedagogical mastery formation. The author's interpretation of the concept teacher' "professional competence" is a complicated complex that includes professional knowledge, skills, readiness for activity, as well as a number of professionally important personal qualities such as: creativity, mobility, sociability, tolerance, tranquility, sensitivity, benevolence, the desire for self-knowledge, self-development and self-realization, self-reflection, and others. The basic components have been defined (gnostic, creative, constructive, communicative and organizational); criteria (formation of scientific and theoretical knowledge, mastery of skills and abilities, optimality of the content selection, methods, techniques, means of teaching, the presence of humanity, democracy and dialogue in communication, effective management of students' educational and cognitive); levels (reproductive, reconstructive and creative level) of the formation of pedagogical skill. According to the author's vision, the model of pedagogical mastery formation of future teachers of the humanities with the use of means of interactive technologies with the following components has been developed and implemented: the purpose of pedagogical mastery formation among future teachers of humanitarian specialties by means of interactive technologies; structural components of pedagogical skill (humanistic orientation, professional competence, pedagogical abilities, pedagogical technique); interactive components of the of pedagogical mastery formation (content, methods, forms and means), which were realized under certain pedagogical conditions of student's education; tasks that are implemented gradually; criteria, components, and levels of students' pedagogical skills formation, is reflected as a result of an experimental study - the formed future teachers of humanities' pedagogical mastery. The educational and methodical provision of the future teachers of humanitarian specialties' training, which is aimed at the formation of pedagogical mastery has been 
substantiated and developed. Educational and methodological support includes a complex combination of theoretical (advanced programs of educational disciplines "Pedagogy", "Basis of pedagogical mastery" and "Foreign language Teaching methods"), practical training, extra-curricular and educational work with the use of various interactive technologies (subject, problem, interactive lectures, press conferences, round tables, trainings, counseling), methods (situation analysis, "mosaic", role play, "snow ball", etc.). The studies that were conducted confirmed the feasibility of pedagogical conditions introducing and the models of pedagogical mastery formation in the educational process of a higher educational establishment.

\section{Introduction}

In modern conditions of the state development pedagogical education faces an acute problem of improving the work of higher educational institutions preparing future teachers with a high level of professionalism and creative activity, those who would responsibly treat their future professional activities. Paradigmatic changes in the goals of education define a new understanding of teacher's functions, abilities, professional skills, oriented to the competence and mastery. This issue is studied by modern Ukrainian scientists: I. Bekh, I. Zyazyun, N. Nichkalo and others. As it was stated in the National Doctrine on Education Development in Ukraine the training of pedagogical staff is a central task of modern education, a guiding principle of state educational policy.

Currently, most of the higher education institutions teach students who are the bearers of certain knowledge, not teacher-professionals, organizers of the educational process. Therefore, the problem of teacher's mastery formation is of great interest to a wide range of scholars.

The peculiarities of the content, structure and manifestations of the teacher's professional mastery was described in the scientific works of such modern scholars as L. Baikova, E. Barbina, L. Grebenkina, I. Zyazyun, L. Kovalchuk, L. Kramuschenko, I. Kryvonos, O. Lavrinenko, O Miroshnyka,V. Semychenko, N. Tarasevych, N. Telychko, I. Kharlamov and others; The connection between creativity and pedagogical maserness was taught by V. Zagvyazynsky, V. Kan-Kalyk, N. Kichuk, S. Sysoeva and others; Professional competence was studied by L. Vashchenko, M. Zhaldak, I. Zymnya, I. Zyazyun, O. Lokshina, N. Nychkalo, O. Ovcharuk, O. Pometun, L. Romanishyshina, O. Savchenko, S. Sysoev, O. Semenogh, A. Khutorskaya etc. 
The dominant activity is training of sucha type of a teacher, whose activities are not limited by teaching a particular subject, but a professional capable to provide interdisciplinary communication, who realizes the importance of professional knowledge in the context of the social and cultural space. His ability to organize the educational process as a pedagogical interaction, aimed at the development of a personality and his or her ability to solve problems in the proses of life-creation is of great importance.

The increased demands of the society provoke changes in the organization of the educational process by introducing interactive technologies into the educational process of higher education. The issue concerning the introduction of interactive teaching in the higher education practice have been revealed in scientific researches by N. Dobrynina, N. Zayachkivska, M. Kozyar, N. Kolesnik, K. Lutsyk, I. Melnychuk, G. Pyatakov, O. Sichkaruk and others. However, the issue of future teachers of humanities' pedagogical mastery formation by means of interactive technologies has not been a subject of a separate scientific research yet.

Special attention to the teachers of humanities' pedagogical mastery formation is paid due to the fact that teachers of this profile should be able to take into account a set of psychological and pedagogical factors that significantly affect the formation of a personality, the basis of such knowledge is laid in the study of humanities.

The purpose of the scientific research is to substantiate theoretically and verify experimentally the pedagogical conditions for the future teachers of humanities' pedagogical mastery formation by means of interactive technologies.

\section{Pedagogical mastery as a component of teacher's professional competence}

One of the problems of modern society is a lack of competent, highly skilled competitive professionals in the labor market. Therefore, high educational institutions should now pay considerable attention to the future teachers' professional skills formation.

Many foreign and domestic scientists studied the problem of the teacher's professional competence: L. Vashchenko, V. Vvedenskyj, M. Zhaldak, I. Zyazyun, M. Kornilova, O. Lokshina, N. Nychkalo, O. Ovcharuk, A. Pometun, L. Romanyshina, O. Savchenko, S. Sysoeva, O. Semenog, O. Khutorskoy and others. 


\section{Romanyshyna Oxana, Figol Natalia}

The goal of this scientific research is to determine the essence and content of the teacher' professional competence and pedagogical mastery as one of its components.

An analysis of modern scientific and pedagogical literature gives us rise to assert that the majority of scientists (V. Vvedensky, R. Gurevich, L. Mitin, S. Molchanov, S. Pilyova, V. Sinenko, K. Shaposhnikov) believe that the teacher's professional competence is a mix of knowledge, habits, skills, experience, as well as his or her personal qualities.

In modern scientific literature two terms which refer to the English word "competence" ("competency") are used, - competence and competency. In English these words are synonymous, but in Ukrainian they have some difference. O. Hutorskyj's interprets the notion of "competency" as follows: "it is a pre-determined requirement to the student's educational training with a goal to master a set of interrelated qualities of the personality, knowledge, skills" [4, p. 4]. While "competence", in his opinion, is "a person ability to possess an appropriate competence, which includes his or her personal attitude to this competence and subject of activity" [4, p. 5].

I. Zimnya interprets competency as "intellectually and personally conditioned experience of a person's socially professional activity which is based on knowledge". By contrast, competence is "a hidden, potential, non-useable reserve" [16, p. 39].

G. Selevko gives the following definitions to these categories: competence is "an educational result that is manifested in the graduate'sreadiness to teaching, in his mastering the methods and means of future occupation, in the ability to cope with the tasks; a combination of knowledge, skills and abilities that allows you to set and achieve the goal of transforming the environment" 12 , p. 139]; competency is "the individual's integral quality which is manifested in his or her general ability and readiness to occupation based on knowledge and experience acquired in the process of learning and socialization and oriented towards independent and successful participation in the future occupation" [12, p. 139].

In "The Dictionary of the Ukrainian Language", the word "competence" is interpreted as "a deep knowledge in something; authorization of any organization, institution or a person" [1, p. 188].

In the definitions of competence mentioned above there is a practical orientation of occupation, value component, reflection.

At the same time, the analysis of existing ground works concerning the 
teache's competence indicates that this time in science there is no unique approach to the phenomenon understanding, there is a heterogeneity of terms used by the authors to denote this phenomena, among which the most common are "pedagogical competence" (L. Mitina), "the teacher's professional competence” (B. Gershunsky, T. Dobud'ko, A. Markova), psychological and pedagogical competence (M. Lukyanova), and also they are considered to be synonyms (Yu. Kulyutkin and G. Sukhobanska).

We strongly hold the view that the above mentioned concepts are synonymous and can be used interchangablly, since they are a kind of pedagogical profession.

The level of teacher's competence in pedagogical problems solving is determined by his or her pedagogical skills.

So, having analyzed the literature devoted to the study of teacher's professional competence, we came to the conclusion that this phenomenon is a complex set that includes professional knowledge, habits, skills, readiness to teach, as well as a number of professionally important personal qualities such as: creativity, mobility, communicability, tolerance, balance, sensitivity, benevolence, desire to gain a high level of self-knowledge, self-development and self-realization, self-reflection, etc.

The concept "the teacher'sprofessional competence" was mostly determined by scientists and the approach has been unified, however, there is no unity of thoughts conserning all ocation of professional competence structural components in general, and teachers in particular.

Thus, vocational and pedagogical competence, according to N. Kuzmina, includes five elements or types of competencies: special and professional competence, methodical competence in the field of methods of students knowledge and skills formation, social and psychological competence in the field of communication processes; differential and psychological competence regarding students' abilities, autopsychological competence of dignity and disadvantages of their own activities and personality [6, p. 56].

In the structure of the teacher's professional competence A. Markova highlited special, social, personal and individual types of professional competence [9, p. 34-35].

The teacher's mastery is determined by the combination of all types of professional competence. In addition, the teacher's competence of can be considered as the unity of the general competence essential for 
a person, regardless of his or her profession, competence in the field of science, the basis of which he teaches, psychological and pedagogical competence.

A great number of scientists (A. Makarenko, V. Mezhererikov, T. Yuzefavichus, etc.) studied the issue: what is the balance between teacher's "professional competence" and "pedagogical skills". A satisfied answer was given by A. Makarenko. Rejecting the assertion about the precondition of pedagogical mastery by innate peculiarities and instincts, he showed that it is predetermined by the level of professional competence. "Pedagogical mastery, based on skills, on qualifications, in his opinion - is the deep knowledge of the pedagogical process, the ability to create it, set in motion" [7, p. 234].

Sometimes pedagogical mastery is reduced to the habits and skills of pedagogical techniques, while this is only one of the components of mastery that manifests from the outside. According to A. Makarenko, mastery of pedagogical skills is accessible to every teacher, if he or she is ready to purposeful work on himself or herself. "Mastery is something that can be achieved. If it is possible to become a famous professional turner, a wonderful doctor, so it is possible to be well-known professional teacher ... And each of the young teachers will gain the mastery if he or she does not leave our occupation, and the level of masteress depends on his or her desire to work hard" [7, p. 235].

Mastery is formed on the basis of practical experience, but not any kind of experience can become a source of professional skill. Only comprehensive hard work in terms of its essence, goals and techniques of occupation can become such a source. Pedagogical mastery is a mix of personal, business qualities and professional competence of a teacher.

Academician I. Zyaziun, a founder of the scientific and practical approach of pedagogical mastery, considers the essence of pedagogical skill as a complex of personality's peculiarities, which ensures the self-organization of a high level of professional activity on a reflexive basis.

These important properties include:

- humanistic orientation (focused on the student's development; seeing not just an individual but a personality, feel, understand and help him or her; to see a big goal in any did; "cultivate" a personality through discovery, rather than inclining; be responsible for own influence; to experience moral satisfaction at the students' development); 
- professional competence (complex of knowledge concerning the subject, psychology, pedagogy, methods, personal coloring of knowledge, constant knowledge updating);

- pedagogical abilities (communicative, perceptual, dynamism, emotional stability, optimistic foreseeing, creativity);

- pedagogical technique (external and internal) [15, p. 29-30].

Studying different points of view concearning the concept of "pedagogical mastery" of pedagogical activity has allowed to conclude that pedagogical mastery is a high level of professionalism, pedagogical culture in professional and pedagogical problems solving, essential personal qualities. Different levels of manifestation of mastery are variants of the teacher's expression of his or her individuality in the profession: from the low, on which the borrowed experience and techniques are repeated, to the highest (creative), where the teacher creates his or her own pedagogical system.

Pedagogical mastery should be considered not only as a high degree of professional knowledge, skills and abilities but also as a certain set of requirements put forward the teacher by specific education system.

\section{Interactive technologies used for pedagogical mastery formation of the future teacher of the humanities}

According to the results of the first "consultative" (konstatuvalnyi) stage of the research, it has been concluded that the technology of teaching used in high educational establishments with its traditional, standard forms, methods, means, content, goals, and objectives of teaching will not promote the formation of future teachers of humanitarian disciplines' (humanities) pedagogical mastery.

Therefore, it is necessary to make changes in the educational and methodological complexes of professionally oriented disciplines, to enrich curriculum with such topics that include the concept "interactive learning technologies", with information about their features, types, peculiarities of the lesson plan using them, peculiarities of interactive lesson planning, the specifics of the the students' activity at such a lesson, the particular features of the teacher's activity at such lessons, the peculiarities of the favorable educational environment creation, the creation of comfortable learning conditions, organization of students' interaction in the classroom, organization of reflection, various forms of mutual learning. The word "interactive" derives from an English word "interact", where "inter" is mutual, "act" - 
act. According to the definition that was found in The Pedagogical Encyclopedic Dictionary by B.M. Bim-Bada, interactive learning is a type of learning that is based on interaction between a learner and learning environment, which is an area of assimilated experience. Ukrainian scientists O. Pometun and L. Pyrozhenko have pointed out that "interactive learning is a learning process that can exist only if there is active interaction among all participants. It is so called co-education, mutual learning (studying in small and large groups), where the student and the teacher are equal members in the teaching- learning process" [11, p. 9].

Special attention was focus to the formation of pedagogical mastery of humanitarian disciplines. We would like to demonstrate the methodology of pedagogical mastery forming at lectures, seminars, practical and laboratory classes, and organization of studying independently independent studying".

Scientists offer an interactive lecture as an alternative to a traditional lecture. In the scientific and methodological literature the following types of interactive lectures have been named and described: a lecture with mistakes, made on purpose, problem-based lecture, lecture with two lecturers, lecture with visualization, lecture-press conference, lecture-dialogue [13, p. 56].

Seminars and practical classes allow the teacher to apply a larger set of interactive technologies than could be used ata lecture: brainstorming, analysis of specific situations, work in pairs, work in small groups, didactic games, and more.

Interactive methods contribute to teach interestingly, provoke new information searchingof [8].

Seminars and practical classes at pedagogical disciplines provide discussion of educational problems in groups. Interactive technologies are used with an aim to make this process more creative, emotionally comfortable, anddevelopstudents'personal qualities.

\section{Model of pedagogical mastery formation of the future teacher of humanities}

In the process of model specification of the pedagogical mastery formation of the future teachers of humanities, the authors relied on different concepts: the system-role model of personality formation (N. Talanchuk) [14], and the pedagogical and psychological structure of the teacher's occupation (N. Kuzmina) [5]. 


\section{Chapter 13. Pedagogical sciences}

The model developed reflects the efficiency of interactive technologies usage in high school by the experimental teaching method which is used to teach future teachers of "humanities". At the same time, this model serves as a source of empirical and theoretical knowledge concerning the possibilities and consequences of a scientifically grounded method "implementing implemented" in future teachers of humanities vocational training.

The graphic representation of the author's pedagogical model is presented in Fig. 1.

The model illustrates that the pedagogical mastery is the goal of combination and interconnection of its components in future teachers of humanititarian subjects by means of interactive technologies; structural components of pedagogical mastery; interactive components of the pedagogical mastery formation (content, methods, forms and means) that were realized under certain pedagogical conditions in the process of students' education; tasks that are implemented gradually; criteria, components and levels of of students' pedagogical mastery formation, reflected as a result of the experimental research the formed pedagogical mastery of future teachers of the humanities.

The first block of the pedagogical model is the goal,that is, a high level of pedagogical mastery formation of future teachers of humanitiesusing interactive technologies.

We consider it expedient to name and characterize the components of "pedagogical mastery".

The study and analysis of scientific pedagogical works and dissertational research allows us to conclude that pedagogical mastery is a characteristic of pedagogical activity, which is carried out at a high level. As to the components of pedagogical mastery, its main characteristic is humanistic orientation.Humanistic orientation of each personality is multifaceted, its value orientations are as follows: directedto oneself(self-affirmation, self-presentation, self-regulation, self-education, self-realization, self-esteem, etc.); to means of pedagogical influence (educational ideals, educational measures, etc.); to a student (development and formation of his personality, assistance his goals achieving, etc.); to methods of pedagogical influence (belief, own example) [2, p. 70].

A second important element of a teacher's pedagogical mastery is professional competence which characterizes the unity of his or her theoretical and practical readiness for the pedagogical occupation, and his or her professionalism [3, p. 69-73]. 
Romanyshyna Oxana, Figol Natalia

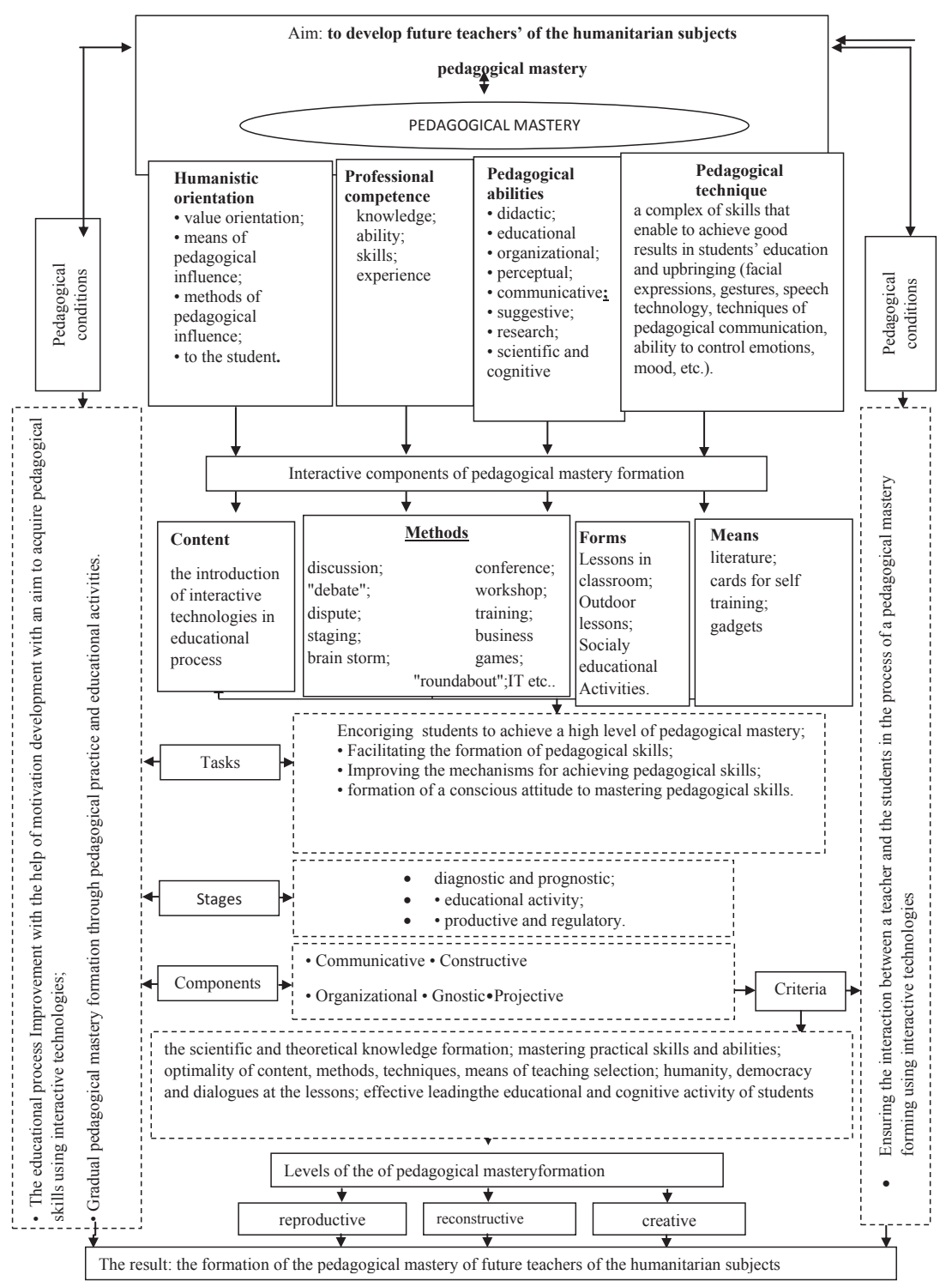

Fig. 1. Structural and functional model of pedagogical mastery formation
of future teachers of humanitarian subjects 
The mastery acquisition is not limited by professional knowledge accumulation. There are individual preconditions for successful activity, stimulators of teacher's professional growth - abilities [15, p. 33].

Psychological researches testify that any professional activity requires not only deep knowledge in one's occupation, but also the development of abilities. On the basis of scientific research (V. Vernadsky, L. Vygotsky, G. Kostyuk, A. Shcherbakov, N. Kuzmina, M. Skatkin, A. Leontiev, etc.) the following leading abilities in pedagogical activity can bedistinguished: didactic, educational, organizational, perceptual, communicative, suggestive, research, scientific and cognitive.

The next component of pedagogical mastery is pedagogical technique as a form of the organizingteacher's behavior. Knowledge, intentions and abilities without skills, teaching methods mastery can not guarantee high results. Pedagogical technique presupposes an ability to regulate teacher's own well-being, the teacher's ability to use his or her verbal and nonverbal means of communication and educational impact on students. Thanks to skill and abilities mentioned above, the teacher creates his or her professional image [3].

The pedagogical conditions contribute to the formation of pedagogical mastery components (gnostic, design, constructive, communicative and organizational). Thus, pedagogical conditions are an improvement of the educational process through the development of motivation with an aim to acquire pedagogical mastery using interactive technologies; gradual formation of pedagogical mastery through pedagogical practice and educational activities; providing interaction between the teacher and students in the process of pedagogical mastery formation using interactive technologies.

The introduction of interactive methods in the educational process: discussions, debates, disputes, staging, brainstorming, conferences, workshops, training, business games, "carousels", information technologies, etc. was effective in pedagogical mastery formation.

In the process of the experimental phase of the research, educational literature, didactic cards, cards for self-training and computer technologies were used for different forms of studying.

For the organization of this study the following study forms were relevant: classroom, extra-curricular, an deducational work.

Important structural elements in the model of pedagogical mastery formation are the definition of the main tasks and stages at which these tasks 


\section{Romanyshyna Oxana, Figol Natalia}

will be implemented. In the process of research, we identified the following tasks:

- to initiate students' desire to achieve a high level of pedagogical mastery;

- to promote the formation of pedagogical skills;

- to improve the mechanisms of pedagogical mastery achievement;

- to form a conscious attitude towards the mastery of pedagogical skills.

The tasks according to the author's model were implemented in three main stages. The first stage, diagnostic and prognostic, provides a clear definition of the goals and objectives of the process of the students pedagogical mastery formation, the justification of methodological approaches to the implementation of this process; development of the program and tools of experimental research, namely: definition of the studied concepts, choice and justification of research methods, development of questionnaires, themes of creative tasks; selection of criteria, indicators and levels of students' pedagogical mastery formation; study of the real state of students' pedagogical mastery formation at the stage of constatation; theoretical justification of the model of pedagogical mastery formation of future teachers of humanities. The second educational and business course is the main stage in the formation of the pedagogical skills of future teachers. This stage involves modifying the system of educational work in educational institutions through the introduction of interactive technologies into the educational process (testing the modules of the program, methodical recommendations for conducting training sessions, presentation of projects); organization of the system of educational events aimed at the formation of pedagogical skills; involvement of students in the use of interactive technologies; the formation of pedagogical thinking, pedagogical experience in the process of passing various types of pedagogical practice.

The third - the effective and regulatory stage of the of pedagogical mastery formation - envisaged the monitoring of the formation of students' pedagogical skills, analysis of experimental work; determining the ratio of goals and tasks to the results of the experiment and determining the range of problems that require further research. Structural components of pedagogical mastery (according to N. Kuzmina) are:

1. Gnostic - research, which involves the continuous increase of knowledge, skills and abilities. This is the ability to explore the process and the result of one' own work. This part of the teacher's activity is most valued by senior pupils. 
2. Constructive - pedagogical activity planning and forecasting the results. This part of the teacher's activity is most valued by adolescents.

3. Designing - designing prospective goals of education and training, as well as strategies and ways to achieve them.

4. Organizational - the organization of the educational process.

5. Communicative - establishing a relationship between the teacher and students [5, p. 48].

In the course of the experiment the following criteria of pedagogical mastery of teachers of humanities are defined: formation of scientific and theoretical knowledge; mastering the practical skills and abilities; optimality of content, methods, techniques, and means of training selection; the presence of humanity, democracy and dialogue in communication; effective leadership of the students' educational and cognitive activities.

There are three levels of mastery: reproductive, reconstructive and creative levels.

The reproductive level is typical for students oriented to the standard of pedagogical activity, which seeks to preserve and maintain teaching skills. The decisive feature of the future teacher with such a level is his ability to teach others in the same way that he was taught.

The reconstructive level of mastery involves the achievement of a positive result of teaching by learning and looking for something new, which is already being implemented somewhere by someone. Future teachers, working at this level of quality, reflect better their individuality in pedagogical activity, and they are characterized by a benchmark for norms of individual progress. The student masters the strategies for the necessary system of knowledge, skills and abilities formation from their subject in general.

The creative level is oriented to the norms, and ideals that set the perspective goals in this type of activity and its individual rules. It is typical for future teachers who are engaged in research work, to have their own teaching methods and be constantly in the creative search. The student has strategies for transforming his subject into a means of forming the students' personality, and their needs of self-education and self-development.

During the research such result was carried out - the formed pedagogical mastery of future teachers of the humanities. Note that this result is possible only when the overwhelming majority of students have a creative and reconstructive level of pedagogical mastery. 
The highest level (creative) of pedagogical skills is provided if a person's pedagogical mastery is considered a value category.

The proposed model reflects the complex implementation of all the pedagogical conditions and components of the future teachers of humanities education identified in the research using interactive technologies at higher educational establishments.

\section{Organization and method of conducting an experiment on the future teachers' pedagogical mastery formation}

At the stage of constatation of the research, 379 students participated. According to the results, it is determined that $80 \%$ of graduates are at the middle and low levels of the pedagogical mastery formation. This led to a plan of research at the formative stage of the experiment.

In the formative stage of the study 115 students participated (57 people experimental group (EG), 58 people - control group (CG)), 8 teachers of Regional Humanitarian and PedagogicalAcademy of Taras Shevchenko in Kremenetsand Yuriy Fedkovych Chernivtsi National University.

On the basis of the experimental research analysis, by observation observation of students of EG and CG, the formation of levels of pedagogical mastery was determined. The levels of formation of each component of future teachers pedagogical mastery in the CG and EG were determined at the input and final stages. For mathematical calculations in order to prove the probability of the results obtained, each of the three levels of the of pedagogical mastery formation was marked on a 5-point scale.

In the process constatational and forming stages of the experiment, no students were found who have no pedagogical skills at all. In order to compare the overall level of pedagogical skills and its components, the average rate (AR) was used for students of CG and EG. The reliability and probability of the obtained results were verified and confirmed using the methods of mathematical statistics, by defining and comparing the F-criterion in the CG and EG with standard indicators.

During the formative stage of the experiment, the following changes took place in the pedagogical mastery formation of future teachers: according to high level index, the number of students of CG increased by $3,44 \%$; in the EG students this figure increased by $38,6 \%$. According to the low level indicators in both groups a decrease in the number of students was noticed: $\mathrm{CG}$ - by $8,61 \%$, and $\mathrm{EG}$ - by $14,04 \%$. The determined indexes of 
readiness levels for the future teachers of the humanities are presented in Table 1.

Consequently, the results of the conducted research indicate that the effectiveness of forming the pedagogical mastery of future teachers oft he humanities using interactive technologies depends on the purposeful and integrated introduction into the educational process of a set of outlined pedagogical conditions, structural and functional models and developed and proposed author's teaching methodologies.

Table 1

The dynamics of the of the pedagogical mastery formation of future teachers of the humanities

\begin{tabular}{|c|c|c|c|c|c|c|c|c|}
\hline \multirow{3}{*}{ Groups } & \multirow{3}{*}{$\begin{array}{c}\text { Kontrol } \\
\text { stage }\end{array}$} & \multicolumn{6}{|c|}{$\begin{array}{l}\text { Number of students and levels } \\
\text { of formation of pedagogical skills }\end{array}$} & \multirow{3}{*}{$\mathbf{R}$} \\
\hline & & \multicolumn{2}{|c|}{ Creative } & \multicolumn{2}{|c|}{ Reconstructive } & \multicolumn{2}{|c|}{ Reproductive } & \\
\hline & & St. & $\%$ & St. & $\%$ & St. & $\%$ & \\
\hline \multirow{2}{*}{$\begin{array}{l}\text { CG } \\
58 \text { st. }\end{array}$} & Imput & 11 & 18,97 & 24 & 41,38 & 23 & 39,65 & 3,8 \\
\hline & Final & 13 & 22,41 & 27 & 46,55 & 18 & 31,04 & 3,9 \\
\hline \multirow{2}{*}{$\begin{array}{l}\text { EG } \\
57 \text { st. }\end{array}$} & Imput & 10 & 17,54 & 23 & 40,35 & 24 & 42,11 & 3,8 \\
\hline & Final & 32 & 56,14 & 9 & 15,79 & 16 & 28,07 & 4,3 \\
\hline
\end{tabular}

The results obtained during the experimental verification of our proposed methodology are a confirmation of its effectiveness and feasibility of introducing into the educational process of higher educational institutions.

\section{Conclusions}

The study makes it possible to state the following:

1. The state of research of the problem has been analyzed, the essence of the main definitions of the research (professional competence, pedagogical skills) has been determined, and features of the process of professional training of future teachers of humanities have been identified.

2. Pedagogical conditions of application using interactive technologies in future teachers of humanitarian subject education have been identified and theoretically grounded.

3. The components have been refined, and the criteria and indicators of the pedagogical mastery formation of future teachers of humanities have been improved. 
4. The effectiveness of the model of pedagogical mastery formation of future teachers has been developed and experimentally tested using interactive technologies.

The research does not exhaust all aspects of the problem of pedagogical mastery formation of future teachers of humanities using interactive technologies. The prospects of further scientific research are seen in the study of this process in foreign theory and practice and students with a low level of pedagogical skills.

\section{References:}

1. Bilodid I. K. (ed) (1979) Slovnyk ukrainskoi movy [Dictionary of the Ukrainian language] Kyiv, Naukova dumka. (in Ukrainian)

2. Kovalchuk L. O. (2007) Osnovy pedahohichnoi maisternosti [Basics of pedagogical skills]. Lviv: Vydavnychyi tsentr LNU imeni Ivana Franka. (in Ukrainian)

3. Kovaljchuk L. O. (2006) Orghanizacija pedaghoghichnoji praktyky studentiv klasychnogho universytetu: kompetentnisnyj pidkhid [Organizing the pedagogical practice of students in the classical university: competent approach]. Proceedings of the Dukhovno-tvorchyi potentsial studentskoi molodi: psykholoho-pedahohichni problemy formuvannia ta realizatsii: materialy III Vseuk. nauk.prakt. konf. (Ukraine, Rivne, May 18-20, 2006), Rivne: Dukhovno-tvorchyi potentsial studentskoi molodi: psykholoho-pedahohichni problemy formuvannia ta realizatsii, pp. 69-73.

4. Kraevskiy V. V., Khutorskoy A. V. (2003) Predmetnoe i obshchepredmetnoe $\mathrm{v}$ obrazovatel'nykh standartakh [Subject and general subject in educational standards]. Pedagogy, no. 2, pp. 3-10.

5. Kuz'mina N. V. (1976) Psikhologicheskaya struktura deyatel'nosti uchitelya [Psychological structure of the teacher]. Gomel'. (in Russian)

6. Kuz'mina N. V. (2001) Akmeologicheskaya teoriya povysheniya kachestva podgotovki spetsialistov obrazovaniya [Akmeologicheskaya theory of improving the quality of training specialists in education]. Moscow: Issledovat. tsentr problem kachestva podgotovki spetsialistov. (in Russian)

7. Makarenko A. S. (1953). Deiaki vysnovky z moho pedahohichnoho dosvidu [Some conclusions from my pedagogical experience]. Kyiv: Radianska shkola. (in Ukrainian)

8. Maksymchuk L. V. (2010) Zasoby interaktyvnykh tekhnolohii u pidhotovtsi ekonomistiv-mizhnarodnykiv [Means of interactive technologies in preparation of international economists]. Proceedings of the Profesionalizm pedahoha $v$ konteksti Yevropeiskoho vyboru Ukrainy : zb. statei za materialamy Mizhnar. nauk.-prak. konf. (Ukraine, Yalta, September 23-25, 2010), Yalta: Profesionalizm pedahoha v konteksti Yevropeiskoho vyboru Ukrainy, pp. 233-235.

9. Markova A. K. (1996) Psikhologam professionalizma [Psychologists of professionalism]. Moscow: Mezhdunarodnny gumanitarnyy fond "Znanie". (in Russian) 
10. Melnychuk I. M. (2011) Teoriia i metodyka profesiinoi pidhotovky maibutnikh sotsialnykh pratsivnykiv zasobamy interaktyvnykh tekhnolohii $u$ vyshchykh navchalnykh zakladakh [Theory and methodology of professional training of future social workers by means of interactive technologies in higher educational institutions] (PhD Thesis), Ternopil: Ternopil National University of Economics.

11. Pometun O. I., Pyrozhenko L. V. (2004) Suchasnyi urok. Interaktyvni tekhnolohii navchannia [Modern lesson. Interactive Learning Technologies] Kyiv: Vydavnytstvo A.S.K. (in Ukrainian)

12. Selevko G. K. (2004) Kompetentnosti i ikh klassifikatsiya [Competencies and their classification]. Narodnoe obrazovanie, no. 4, pp. 138-143.

13. Sichkaruk O. I. (2006) Interaktyvni metody navchannia u vyshchii shkoli [Interactive methods of teaching at a high school]. Kyiv: Takson. (in Ukrainian)

14. Talanchuk N. M. (1991) Vvedenie $v$ neopedagogiku. Posobie dlya pedagogov-novatorov [Introduction to neopedagogy. A handbook for teachersinnovators in] Moscow: Logos. (in Russian)

15. Ziaziun I. A., Kramushchenko L. V., Kryvonos I. F. (2004) Pedahohichna maisternist [Pedagogical mastery]. Kyiv: Vyshcha shkola. (in Ukrainian)

16. Zimnyaya I. A. (2003) Klyuchevye kompetentsii - novaya paradigma rezul'tata obrazovaniya [Core competencies - the new paradigm of the result of education]. Higher education today, vol. 3, no. 5, pp. 34-42. 